\title{
The Diaspora and Socio-Economic Roles of Muslim Migrants in the City of Dasmariñas, Philippines
}

JOSE AIMS R. ROCINA ${ }^{1}$

ABSTRACT

This study focuses on the factors of migration of Muslims from Mindanao to Luzon, specifically the City of Dasmarinas, Philippines. It also provides data on the present roles of such migrants to the development of the city and their thematic traits as a people. Culled mainly from 12 interviews and with analysis adapted from Moustakas, et.al. Model; the main reason for their migration according to interviews is the search for new opportunities; their belief that they would earn more in the establishments of the city. Their decision to migrate is also influenced by persons close to them such as relatives. The interviewees have quickly adapted to their new environment by traveling together and settling with their families. Ethnographic approach unraveled that aside from paying taxes to the coffers of the city and rent to its businesses, Muslim migrants have contributed to the city's progress by engaging in work; providing aid during calamities, charitable works and cheaper products to the city's inhabitants. Employing a qualitative case method, and using informal and in-depth tools; the study concludes that the Muslims of Dasmarinas have not only enriched the socio-economic aspects of the city, but have also greatly contributed to its over-all growth and productivity.

Key words: migrants, Muslims, socio-economic.

It is apparent that prevalent wars, climatic conditions, political and economic (Stark,2003) upheavals in the past decades have brought contingent migratory events/diaspora in different parts of the globe resulting to displacements and incidental settlements of people in many countries. This exodus of nations within a nation has brought political, social and even economic complexities around the world. Example in the 1960's (Hilsdon 2006); Sabah, Malaysia has accepted Filipino Muslim migrants from Mindanao when war against Muslim insurgents escalated. This movement has raised issues of socio-economic roles in society, which changes not only the distinctive spatial features of nations but also gave birth to the idea of coherence in economic and social structure. In her study, Lacar (1989); said that Muslim migrants e.g. Maranaos began to migrate then, due to "push" and "pull" factors.

In the traditional society, the mode of division is through families and tribes; kinship relationship is the basis in the grouping of early people. But modernization through assimilation and acculturation has brought this primordial society to expand physically and economically, making the society that we know today more socially intricate. This is further accentuated by (Fellman 2005) current societies grouping themselves according to income, occupation (social status), stages in the life cycle (family status), language and economic status. Furthermore, as a city

${ }^{1}$ Jose Aims R. Rocina, PhD, Professor of Political Science, De la Salle University-Dasmarinas. Congressional Avenue, Dasmarinas, Cavite, Philippines 4115. Email: jrrocina@dlsud.edu.ph

https://doi.org/10.24035/ijit.19.2021.193 
becomes more complex, the more likely its residents will embark on segregating themselves into groups based on social, family and economic standing (Stark 2003). These events also brought problem to the migrants in defining their roles in the host community.

This study through phenomenology focuses on the issue of socio-economic roles of migrant local Muslims; their current state and condition as part of the society. If we will rationalize the basis of this geographical tendencies and adjustments, it is perceptible that this occurrence is an instinctive impulse by the minority group driven by self-preservation. Thus, making this people secluded or superficially attached to the community that they are residing. Indeed, their motivations to interact and cooperate are restricted towards the preservation of the group. Thus, for Gagarin (2009), the perspective of Filipino Muslims had become important factors in their current conditions in their new places of resettlement.

This research ventures on the complexity of socio-economic roles; diaspora and the intentionality to engage in mutual cooperation and the factors that shape their identity as members of a new community e.g. Dasmarinas City, Cavite, Philippines. This is a phenomenon that needs to be studied to empower and encourage our Muslim counterparts to participate and be involved in the host society. Indeed, Muslims (Eder 2010) had learned to develop and cultivate political and social ties with their non-Muslim counterparts. The significant contributions of this study are the following: (1) To provoke synergy among citizens of our community to participate in the coherent effort of building our nation, (2) to serve as an eye opener to our authorities for them to be more responsive to the needs of these ethnic groups by offering policies/programs for the development of its citizens particularly the so-called minority or suburban groups and (3) to serve as a pinnacle of contextualization of national and global socio-economic issues .

This study seeks to pulse the reason of the Muslim migration, and how they see their socioeconomic roles in the community. It is still occurring and will continue to re-occur in our present society if we will not be continuously vigilant and educate our populace especially the young generation who are exposed to mass media exploitations and thus, inculcate in them the importance of tolerance and social relativity. In the same extent, the inclusivity of the Islamic religion has brought a wider gap of achieving social and economic pluralism and relativity among majority and minority groups in our community. This has resulted to the fragmentation of our society as Filipinos; therefore, unity amidst diversity is what this study is all about.

The study focuses on the situations that shaped the Muslim migrants' decision to transfer and the role of the people close to them in influencing their plans. It also delves into the different ways that such migrants adopted to adjust to their new settings and likewise, their socio-economic roles as members of the community. Finally, finding their individual traits as a people is also vital to the aims of this research.

\section{Methodology}

This study uses the qualitative approach. Qualitative Research as used in this study, focuses on obtaining data by propounding open-ended and conversational communication (question pro.com). Its aim is to clarify the intentionalities of selected Muslim migrants residing in Barangay Datu Esmael of Dasmarinas City, Cavite, Philippines. It makes use of ethnographic-methodological techniques in the gathering of experiences in an effort to delve into the background of their intentionality to migrate, the network of factors influencing this intentionality and thus, gain insights on the role of Muslim migrants as a people.

The key informants are 12 in denomination (one male and eleven females), most are traders (Prufonga \& Sulleza 2016), Dasmarinas residents for at least 5 years, and preferably voters of the city. The Pakapa-kapa at Patanong-tanong (Informal Interview) technique is utilized to find key information and arrive at substantial findings. Describing the intentionality requires an appropriate method of gathering experience and this is through an in-depth, life story and focused interviews, a

$$
\text { https://doi.org/10.24035/ijit.19.2021.193 }
$$


self-made questionnaire was prepared by the researcher as a guide for the interview but was not shown to the respondents so that the spontaneity of the discourse is not structured and interrupted.

A tape recorder is used to record the content of the interview. The entire process of the interview was subjected to Phenomenological bracketing or Epoche (Husserl on Perando, 2009); this is the suspension of judgment or abstention or "bracketing of all latent prejudices so that the true phenomenon can come to light." In the analysis of the foregoing study the researcher made use of Moustakas- Colaizza - Cuyos Model (Esteban 2001; Cuyos 2008 \& Lim 2010). Part of the steps in the analysis of experiences include the repeated playing of the recorder and writing its contents in a verbatim manner. Afterwards, the researcher read and reflected on the written statement of the respondent migrants using thematic reflection, then the data was written in a journal. All these written interviews were subjected to data reduction to select the sentences and phrases which have value on the topic being studied (Cuyos 2008).

\section{Results and Discussions}

\section{Situations and Factors that Shaped Muslim Migrants and Their Decision-making}

Migration is defined as the movement of people from one place to another and is considered as an integral part of human behavior. These persons are called migrants and one pattern of migration which can be considered as dominant is the movement of population from rural areas to the urban. (Payne \& Nassar 2012). In the Philippines, the Muslims of Mindanao are a traveling people, using their trading vessels (Makol-Abdul 1997). From the hinterlands of the South, they move their families to the more progressive communities of the north in search of new identities, greener pastures (Lacar 1989) and a better tomorrow.

Some of these people are specifically searching for new opportunities and this is one of the main reasons why they left the south; to be in a good economic situation and be at par with other progressive Christian communities. Hilsdon (2006) mentioned the migration for example of Filipinos to Sabah, Malaysia to escape grinding poverty in the county. Indeed, while the main occupation of Muslim residents are traders; many Muslims nowadays are also engaged in jobs such as barbers, waiters, drivers in order to survive.

A number of those interviewed would interpose that it is the pervasive violence in the South which had led them to leave their places of origin and search for more peaceful communities and settlements. This view is buttressed by Reza (2018) who posited that Muslim migration in Western Europe was caused by wars and other forms of violence. But this perspective is limited to a few.

Indeed, many of those interviewed would suggest that the movement of Muslims from the South to the North is brought about by their desire to uplift their meager incomes by engaging in what they do best: doing brisk business by selling various commodities and household goods in the markets, malls and even in sidewalks. In a study, Gagarin (2009) likewise added that people are often inclined to adapt with whatever they could find in the vicinity. However, when the situation is no longer tolerable and limitations are breached, people search for more livable environments and a craving for a change in environment then appears.

A number of migrants would interpose that it is the government's bias (Eder 2010) in serving people of the South; resulting in underdevelopment which led them to ply their wares in Luzon. This is relative to some programs of the government which prioritized only residents near the greater Manila area, to the detriment of localities far from the center. In terms of development projects such as roads and bridges; the restive south is also being left behind as the national government focuses on massive infrastructures which benefit more people; usually found in the 
local governments of Luzon. One of those interviewed also said that migrant Muslims migrate to other regions to spread the religion of Islam; although this is not the majority view.

It can be concluded that nobody really influenced Muslim migrants to travel from the confines of the south except themselves. According to majority of them, they undertook it to improve their lives and that of their families; and to help them charter a brighter future. In some situations, they migrate because their businesses are not faring well and their families cannot anymore live in comfort. This search for greener pastures (Prufonga \& Sulleza 2016) is one of the motivating factors which impacted the decision of Muslim minorities to move from Mindanao to Luzon and even the Visayas regions. Parents sometimes, influenced the migration of Muslim children; especially for well-off families who can send their children to institutions of higher learning in Luzon. Believing that education is the key to their success, these parents have conditioned themselves for separation from their off-springs to better prepare them for what lies ahead.

The constant violence (Lacar 1989) in the war-torn South specially in the 1970s and 1980s has also taken its toll on some of these followers of Islam. Believing that the only means of escape from the possibility of harm or even death (Sietze et. al. 2011) is the transfer of residence, these Muslims pack up their things and leave everything behind. Other influential persons in this quest for finding new and better communities include also their teachers and the Imam or religious heads. These teachers have great influence on the lives of their students. Other religious leaders also hope that these Islamic seeds could lead the way in converting other Filipinos to their religion.

\section{Socio-Economic Roles and Adjustments in a New Setting}

In a new social setting and background, these Muslim resident migrants must now find a way to adjust and prepare themselves for the perceived difficulties ahead e.g. cultural and political aspects (Stark,2003). In reality however, it is much easier for these new inhabitants to settle in their chosen areas of settlement as they will be living with their relatives who are already stable and settled in Luzon. Most research participants no longer saw the need to adjust as they just stay with these relatives who have already established themselves in the city. This is one of the social ties that bind Muslim communities together; strong family affiliation and kinship (Lacar 1989). Thus, Muslims usually reside in specific communities with their tribes such as the Maranaos of Datu Ishmael in Dasmarinas City and the Tausugs of Culiat compound in Quezon City, respectively.

The most important factor of course to consider here is that; Muslims are highly dependent on their own tribes for faster assimilation and acculturation in a new social environment. This strong bond of tribal ties makes their transition a lot easier and better-managed. For those few migrants who find it hard to adjust to the new social milieu; they wholeheartedly engage and preoccupy themselves on their new tasks or present employment.

Some Muslim resident migrants contribute to the community through various charitable activities like giving food and alms to the less privileged. And indeed, they assist other Muslims specially during the fasting period of Ramadan, providing food to the needy at approximately six in the evening. Vladimirovna (2019) highlighted the role of Muslim migrants in such social undertakings and projects. They are also very much united with their communities and this unity has served them well in times of crisis and hardships and thus, they try to assist each other in such situations. They likewise give food to their fellow Muslims brothers and sisters who are in dire need of necessities and also provide money as donation for the mosque and other community needs. They also pay rent to stalls owned by private individuals and the government and; remit their corresponding local taxes to the authorities.

It is important in this part of the study, to take note of the local presence of the Islamic Studies Call and Guidance (ISCAG); a local Muslim entity established by the Muslims in Dasmarinas

$$
\text { https://doi.org/10.24035/ijit.19.2021.193 }
$$


City to provide affordable education, attention and comfort to fellow followers of Islam. Aside from sustaining the needs of Muslim residents in the city, ISCAG also provides assistance to victims of calamites such as typhoons. Indeed, Muslim migration (Karpat 1996) plays a crucial role not only in spreading the Muslim faith but also in creating a new society which is achieved through a massive integration of different cultures.

Muslims who earn as vendors at the local marketplace of the city, Kadiwa Market also contribute to the local economy by providing cheaper goods and other items to their customers and other shoppers alike. The rent that they monthly pay for their stalls also fatten the coffers of city funds. Some of those interviewed provided very good insights; such as always following the rules and regulations of the city's leadership structure and striving to be a good example to fellow Muslim residents by obeying the law and exercising their rights and duties as good citizens of the locality. Groves (2012) pointed to this as the primary role of such migrants in the formation and development of cities. Many Muslim migrants also established their niche in the community by engaging in different occupations such as being a barber, a tailor or a baker. Others are even more adventurous by engaging in big businesses such as being a Halal restaurant owner or a shop enterpriser. Their concern for others should also be given consideration as they give donations to the poor and provide assistance to those in difficult situations. Most of these Muslim migrants are now contributors to the development of the local areas where they reside. They have embraced their roles as helpers of development by putting up schools, places of worship and business entities.

\section{Thematic Traits of Muslim Migrants}

In a nutshell, various interpretations can be gleaned from the findings of the study which are the following:

1. The theme of being united and peace-loving- This is very much alive in the lives of Muslim communities e.g. migrants as they are intricately united in their goals of providing better standards of living to their love ones. Ruiz (2018) posited that Islamic migrants are united in their observance of Islamic values such as cleanliness, peace and unity. It could also be surmised from their actions that they are really lovers of peace and do not want to engage in violent activities. They are living peacefully in their communities except for some occasional disturbance.

2. The trait of family and tribal orientation- Muslims are also very much attached to their clans. Many of them make their decisions based on what is good for their families. The Muslim migrants basically want to be with their tribes in their new communities in the Luzon area. We have as an example, the Maranaos living in Datu Ishmael, Dasmarinas City and the Tausugs of Culiat compound in Quezon City, Philippines to illustrate their strong adherence to tribal connections. Particularly for Lacar (1989), Maranaos are die-hard clannish and extremely family-oriented.

3. The characteristic of being business-inclined and hardworking- It is also strongly observed that these Muslim migrants engaged in trade (Prufonga \& Sulleza 2016) in the commercial centers of the city. They sell basic goods in the markets and gadgets in the malls although sometimes they sell both. They also have other businesses near their communities. They are striving and exerting much effort in their places of businesses as they labor sometimes in the prevailing hot conditions or thrive even in untidy environments. They are very focus in providing food on the table for the people close to them. 
While there are many reasons why Muslims left their zones of comfort in the South; the most outstanding reason is their search for greener pastures (Lacar 1989) in order to provide a better standard of living for their families. This desire to improve their plight and be equal with their Christian counterparts has ignited in them the desire to travel far. Believing deep in the inner recesses of their beings that they will earn more in the commercial areas of Luzon than in the confines of the South, Muslim residents migrate to the north.

Although it is possible that some influential persons impacted on the minds of these Muslim residents to migrate from Mindanao; it is believed that they have made such life-changing decisions on their own after consultation with fellow relatives in the inner circles of their families. Thus, love and respect for their families are the main reasons for such decisions. And the transition is often seamless as they will just be living with their relatives who have arrived in the city before them or with their fellow tribal neighbors who have already established their livelihood and residences in the cities e.g. Dasmarinas. This unity and kinship is an important aspect of Muslim culture.

Finally, these new resident migrants have become productive members of the community by engaging in different forms of livelihood opportunities. Stojkow (2018) has emphasized these roles of engagements practiced by both migrant sexes. Being businessmen has indeed, provided Muslim migrants ample opportunities to contribute to local economies and this love for industry has made them essential actors to the growth of local communities. As businessmen, they have become important economic contributors to society by paying rent and taxes to local authorities and providing affordable goods and services to their fellow citizens.

\section{References}

Cuyos, F.A. 2008. A Phenomelogical Inquiry of the Bahay-Lingkod Community Center (BLCC): An experience of People Empowerment and Evangelization. Doctoral Thesis. Asian Social Institute, Manila, Phillipines.

Denzin, N. \& Lincoln Y. (eds). 2003. The Landscape of Qualitative Research. London: Sage Publication

Eder, J. 2010. Ethnic differences, Islamic consciousness, and Muslim social integration in the Philippines. Journal of Muslim Minority Affairs. 30(3): 317-332.

Esteban, C. 2001. Isang Penomenolohikal na Pagdulog sa Kaalamang Iral ukol Sa Pag-aaral ng Heograpiya. Master's Theis. Philippine National University.

Fellman, J.D., et. al. 2005. Human Geography Landscape of Human Activities. 8th Edition. New York: McGraw Hill.

Frufonga, R. and Sulleza, V. 2016. Establishment of a migrant community: the story of the Jamahs in Ilo-ilo City, Philippines. Asia-Pacific Journal of Multi-Disciplinary Research. 4(1): 6-12.

Gagarin, M. 2009. Metro Muslim: A Study on the Resettlement of Filipino Muslims in Metro Manila. http://dspace.cas.upm.edu.ph:8080/jspui/handle/123456789/358. Retrieved: July 5, 2020.

Groves, Z. 2012. Urban migrants and religious networks: Malawians of Colonial Salisbury, 1920 to 1970. Journal of Southern African Studies. 38(3): 491-511.

Hart, C. 2005. Doing your Master Dissertation. London: Sage Publication.

Hilsdon, A. 2006. Migration and Human Rights: The Case of Filipino Muslim Women in Sabah, Malaysia. Women's Studies International Forum. 29(4):405-416.

Karpat, Kemal. 1996. Muslim Migration: a response to Aldeeb Abu-Sahlieh. The International Migration Review. 30(1):79.

Lacar, L. \& Lacar, C. 1989. Maranao Muslim migration and its impact on migrant children. Philippine Studies. 37(1): 3-14.

Makol-Abdul, P. 1997. Colonialism and change: the case of Muslims in the Philippines. Journal of Muslim Minority Affairs. 17(2): 311-313.

Moustakas, C .1994. Phenomenological Research Methods. London: Sage Publishing.

$$
\text { https://doi.org/10.24035/ijit.19.2021.193 }
$$


Payne, R.J. \& Nassar J.R. 2012. Politics and Culture in the Developing World. Boston: Pearson Education.

Qualitative Research: Definition, Types, Methods and Examples. https://www.questionpro.com/blog/qualitative-research- methods. Retrieved: July 5, 2020.

Reza, A. 2018. Muslim, diaspora, Muslim transnational communities and education. International Handbooks of Religion and Education Handbook of Islamic Education. Sweden: Springer Publication. 415-434.

Ruiz, A. 2018. Muslim Migrants and hybrid placemaking of Mosques in Culiat, Quezon, City. Kasarinlan: Philippine Journal of Third World Studies. 33(2): 44-88.

Sietze, et.al. 2011. The agrarian roots of contemporary violent conflict in Mindanao, Southern Philippines. Journal of Agrarian Change. 11(3): 298-320.

Stark, J. 2003. Muslims in the Philippines. Journal of Muslim Minority Affairs. 23(1): 195-210.

Stojkow, M. 2018. Polish ummah? the actions taken by Muslim Migrants to set up their world in Poland. Central and Eastern European Migration Review. 7 (2): 185-196.

Vladimirovna, R. 2019. Migrants and conflicts within the local ummah of the Perm Krai: a playing card or a social factor? Stanovnistvo. 57(1): 97-111. 